\title{
COVID 19 AND THE LOOMING THREAT OF AGROTERRORISM
}

\section{DR SHARAD S CHAUHAN}

Indian Police Service, Additional Director General of Police, Punjab

\begin{abstract}
The most frightening and potentially catastrophic scenario for an assault on a nation and humanity would be an Agroterrorism attack released on livestock or crops. The gain of function experiments worldwide has further increased the need to revamp our biosecurity and bioprepardness. Significant gaps however exist in our capabilities to prevent, plan, respond and pull through from any such acts of terrorism. In a slacking agricultural sector farms are a weak link in the "farm-to-table continuum" which is an alarming prospect as sneaking in an unknown pathogen, is hardly a noticeable security breach. Any such act will end up causing economic crisis, social unrest, and loss of confidence in government. The COVID 19 pandemic is an agonizing example of the damage that pathogens can cause worldwide and has exposed the inherent weaknesses and inequity in pandemic preparedness and response by exposing the fault lines. The lessons learned should act as an alarm bell to take preemptive steps to review our Agroterrorism preparedness.

This review attempts to define the threat of Agroterrorism from a security and scientific viewpoint, provide a historical survey of events with case studies and discuss the problem to aid scientists, policymakers, and agriculturalists to plan against those who would cause harm. It aims to create proper awareness and recommends the implementation of multi-prong strategies to enhance security of our agricultural resources.
\end{abstract}

KEYWORDS: Agroterrorism, COVID 19, Preparedness, Plans, Strategies, Gain of Function Experiments

Received: May 09, 2021; Accepted: May 29, 2021; Published: Jul 10, 2021; Paper Id.: IJASRDEC20219

\section{INTRODUCTION}

"For the life of me, I cannot understand why the terrorists have not attacked our food supply because it is so easy to do." Said the Former Secretary of the U.S. Department of Health and Human Services, Tommy Thompson 7 December $2004 * 1$

COVID 19 pandemic has impacted the lives of billions of people. Terrorist organizations actively seek to have the same effect on our lives and the economy making bioterrorism an effective model for future terrorist activities by striking at international vulnerabilities. The struggle to tackle the COVID 19 pandemic has exposed the vulnerability to natural and manmade biological threats, prompting experts to warn of a potential increase in the use of biological weapons, like viruses or bacteria, in a post-coronavirus world. The COVID 19 pandemic has highlighted the significance of preparedness plans, rapidly emerging scenarios that might develop and the kinds of capacities that will be needed. The emergence of COVID 19and the preoccupation of nations preparing for the next biological event could prompt the terrorists to launch agroterrorism attacks. Among all forms of unconventional methods used by the terrorist employing biological agents, agricultural bioterrorism (including livestock) is the most ignored yet the most dangerous form of asymmetric engagement strategies.

There has been no universally accepted or formulated definition of Agroterrorism but a proposed working definition is "The use of biological agents, devised against agricultural or farm targets including crops, livestock, 
sea or water resources with the aim of causing widespread damage and destruction to the target as well as its owner or state, where the target is situated to create economic, social, political impact and affect biodiversity to achieve the perpetrators aim".

Corrie Brown an Agroterrorism expert at the University of Georgia feels that conventional bioterrorism would fail in front of agricultural bioterrorism if the sheer economic impact of the act were considered. *2

\section{AGROTERRORISM: HISTORICAL OVERVIEW}

Discussing the historical overview of Agroterrorism is important because it would help us conceptualize the threat.

The Germans first experimented with Biological agents during the First World War by sabotaging draft animals and cavalry of America, France and other countries with Anthrax and Glanders. During the Second World War Germany conducted offensive research with Foot and Mouth Diseases (FMD) and conducted open air experiments on cattle on an island in Lake Peipus in Northern Russia *3. Around 140,000 potato beetles were dropped from air in October 1943 near Speyer as a part of a biological weapon program *4 Other German experiments included testing potato tuber decay, antler moth's turnip weevil, turnip bugs, and potato stalk rot disease agents. *5 The Japanese during the Second World War experimented with fungi, bacteria and nematodes on a variety of Crops grown in Manchuria and Serbia*6. During 1940-41 aerial dispersal of infected grains of wheat, millet along with microbes of Anthrax and Glanders were reported in Occupied China. * 7 The French conducted research against the staple potato crop using potato beetles. They were released from high altitudes during field trials at Cazaux*8. The potential of Rinderpest virus against various cattle were also explored. $* 9$

The British as early as 1937 through the Microbiology Warfare Committee produced its report on the potential use of Anthrax, Plague and Foot and Mouth Disease (FMD). Anthrax was developed as anthrax cakes to be delivered through aircraft over enemy territory. *10. The United States had developed many agents against plants and animals including wheat steam rust, blast fungus of rice, Foot and Mouth Disease and rinderpest. Till the year 1969 when it renounced its Biological Weapons program, it carried out more than 30 tests on crops and had stored rice and wheat blast fungus at Fort Detrick, Maryland and Rocky Mountain Arsenal, Denver Colorado *11. In 1935 stem rust of wheat was the first anti-plant agent standardized by the US Chemical Corps. *12 In the early 1960s around 5,000 Kilograms of anti-plant Biological Warfare agents was available in the United States. *13 In the period between 1964-65 The United States tested anti-animal pathogens in stockyards in Texas, Missouri, Minnesota and Nebraska *14. The Central Intelligence Agency has acknowledged that it had a developed plan for covert attack in the agricultural sector that could inflict very serious and severe Crop damage $* 15$ The ex-Soviet Union was far ahead of the rest in the field of Biological Weapons against plants and animals. The Soviets conducted research with potato viruses' tobacco mosaic virus wheat mosaic streak virus and brown grass mosaic virus, wheat fungus and brown leaf rust among other anti-plant pathogens *16. Among the anti-animal pathogens, they experimented with FMD, rinderpest African Swine Fever (ASF) contagious ecthyma of sheep, avian influenza, vesicular stomatitis viruses, and bovine contagious pleuropneumonia*17. They successfully used insects to transmit plant pathogen, ticks to transmit FMD, and avian ticks to transmit Ornithosis to chicken. * 18 The Soviets were also ahead in weaponization. Lyophylization and vacuum storage were conducted on maize rust. New castle disease virus was also stabilized $* 19$. They had mass rearing facilities to produces millions of parasitic insects per day $* 20$. Migration and release pattern for insects was studied using radar to test and quantify their anti-crop potential. *21 


\section{GAIN OF FUNCTION RESEARCH: THE GHOST OF SARS COV 2}

Gain of function research is a term used to describe any field of medical research which alters a pathogen in a way that increases pathogenesis, transmissibility, or host range in order to predict emerging infectious diseases or to develop vaccines and therapeutics. The possibility of the role of gain of function experiments conducted on corona viruses and the possible emergence of SARS CoV 2 has been discussed in literature *22. Similar studies are being conducted on animal pathogens including that of FMD. One such study $* 23$ observes "the adaptation of a field isolate of the virus to grow in culture is laborious and time-consuming. This is of particular concern for the development of vaccines to newly emerging virus lineages and can delay the implementation of effective control programs. A rational approach to cell culture adaptation that combines prior knowledge of common adaptive mutations and reverse genetics techniques is urgently required. The ability to engineer recombinant viruses with enhanced growth properties in cell culture can be of great benefit.

\section{ADVANTAGES OF CONDUCTING AN ACT OF AGROTERRORISM*24}

Easy availability of the agents through natural outbreaks or from nature and the fact that most biological agents against agriculture are robust is the foremost advantage. The agents are easy to weaponize or need no weaponization. In the case of Foot and Mouth Disease, the scraping of a lesion and subsequent spread to other animals is an easy task. It presents a low hazard scenario for perpetrators, as most of the plant and animal diseases do not affect humans (or terrorists!) It is associated with a low or no moral guilt, as it does not involve the killing of humans. It is usually presumed that most of the diseases are natural due to ineptitude and not attributed to terrorism. It can be done remotely by not visiting the proposed site as in the case of shipping of contaminated seeds and other products. Unawareness of this form of terrorism even amongst the intellectuals and bureaucracy, least of all the farming community makes it easy to perpetuate. Commercialization of agriculture especially farms and animal breeding, leading to genetically uniform crops and livestock makes it an easy target for pathogens. The outbreak spreads fast as most are communicable diseases. No detailed knowledge or technology is needed for either production or delivery of agents. Multiple approaches are possible. Crops can be infected from the top (area spray) or bottom (by contaminated seeds or water). Recognition of events is delayed leading to escape of the perpetrator. It may create panic and lowers the confidence of the people in the Government. Zoonotic diseases like Anthrax and Glanders might spread to humans. Destruction of the carcasses, killing of apparently normal animals and disposal of carcasses adds to the economic and social burden. Retaliation becomes difficult as the perpetrators and their supporters are difficult to identify. Agricultural resources like plants and animals, as opposed to humans, are largely unprotected making it easier to conduct an act. Hoaxes in the agricultural sector are of more dangerous nature as it leads to panic, as it is part of our food chain.

The changes in agricultural practices have led to consequences, which could aggravate any attack on the agricultural sector. There has been an increase in the size of animal farms making the spread of diseases easier. Higher inbreading in animals and uniform patented seeds (monoclonal) in plants lowers genetic diversity and increases susceptibility to diseases. There is a scarcity of vaccines as most diseases are controlled or sporadic. The increase and often indiscriminate use of hormones, steroids, and antibiotics has led to a decrease in innate immunity in animals. In the case of state-sponsored actors, the use of knowledge about genomics and proteomics for matching genotype specific weapons is not a difficult task for perpetrators with sufficient resources. 


\section{ECONOMIC IMPACT OF AGROTERRORISM}

Economic impact of Agricultural bioterrorism is the most important implication of this type of terror. Although the figures which will be quoted are for economic losses caused in a normal outbreak, it would not be difficult to extrapolate the same to deliberate induction of these diseases.

The 2001 incidences of FMD in the United Kingdom had very dangerous consequences. The Incremental cost of lost meat and livestock exports were estimated at US\$ 2 million per day. More than 4,000, 000 animals were destroyed within the affected FMD areas of UK. The cost of slaughter and destruction of infected livestock was to the tune of U\$ 7.5 billion. The direct cost of containing the 2001 epidemic of FMD in UK was far less than the indirect cost in the form of lost income, loss in investment and in the non-agricultural sectors of the economy. Estimated economic losses to tourism industry were estimated at U\$ 350 million per week or 25 times higher than direct costs. (Estimated at around U\$14 million per week) The negative publicity in the media cost U\$ 4 billion to the tourist industry. The total loss estimated for the 2001 FMD outbreak in the UK is estimated to be $\$ 3.1$ billion pounds or 6 billion dollars both as direct and indirect costs. The uncompensated losses to farmers were to the tune of 675 million dollars or $20 \%$ of UK's farm earnings *25 Price Water House Coopers has estimated that 2001 FMD in UK could ultimately have caused a loss of 11.6 billion dollars and a similar outbreak in the United States could have affected 53 million cattle 1.4 million hogs 800,000 Sheep and could have caused the US economy a loss in between 1.4 to 33.6 billion dollars *26

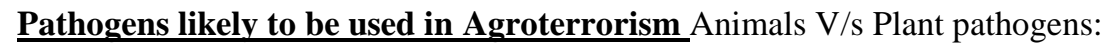

Animals could be the more likely target for a terrorist attack as compared to the crops. Animals have more attachment as assets to humans. The diseases are more likely to spread as infected animals are reservoirs for further disease spread. The animals are mobile and hence disease can spread faster than for crops. Certain pathogens are zoonotic i.e. can spread to humans. Infected animals could cause a chain reaction as their products like milk, wool, and meat are further raw materials for a variety of other business enterprises, causing a chain of economic losses. Buffer stock of crops is available in most of the country whereas the same is not true for animal products. Plant pathogens are more difficult to manipulate at the level of terrorists. Plant diseases (as plants are static in nature) take a longer time to spread or establish. Many plant pathogens require strict conditions of environmental variables like temperature humidity, or wind to spread optimally. All these points make plant pathogens less attractive to terrorists as compared to animal pathogens.

Animal and plant diseases agents liable to be misused have been variously classified by FAO/WHO/OIE according to their importance and rapidity of spread.

\section{TECHNICAL/FEASIBILITY ASPECTS OF AGROTERRORISM}

Unlike conventional Bioterrorism no technical advancement is required to plan and execute an attack against agriculture. Simple possession of the agent from an infected animal or plant would suffice. A perpetrator with basic knowledge about microbiology or even an expert farmer can visit an area of occurrence of FMD and obtain a lesion by scraping or through basic culture techniques increase the number of pathogens and intentionally start a small epidemic without sophisticated knowledge or expertise *27. Multiple and simultaneous attacks like these can be planned. The infected clothes of herdsmen can also spread FMD. *28. Pathogens having a large incubation can also be chosen so that large herds are simultaneously infected before any attack is noticed *29. It is also possible to infect reservoirs of the disease (wild animals which are themselves not affected by the disease agent) so that disease continues to reappear in the place making its 
eradication difficult

As compared to animal diseases, plant diseases are more common but difficult to perpetrate. Air does not disperse crop disease to the extent of animal diseases. Plants are also stationary whereas animals are ambulatory. Crop agents are also sensitive to environmental factors like temperature, humidity UV rays etc. In addition, some technical expertise like aerosol formulation would be required for wide dispersal by aerial route just as it would be for human pathogens $* 30$. However, this fact is compensated to a terrorist by the reality that even slight infection, when detected in seeds or grains when they are collectively acquired, could be grounds for rejection of the same or even imposition of export restrictions. This could start a form of surrogate warfare between two nations. There is a possibility of the spread of plant diseases through vectors which could circumvent the limitations in inflicting damage in large areas. An example in this regard would be the spread of cotton leaf curl virus through whiteflies. It is estimated that the traditional systems of agriculture are being replaced by intensive agriculture at the rate of $4.3 \%$ animal holding units per year with a majority of the increase in the regions of Asia, South America and North Africa * 31. The quoted figures indicate that the spread of intentionally introduced biological agents by perpetrators could be even faster than anticipated and create enormous socio-economicalpolitical impact in the target society as needed by a terrorist or any other player.

\section{POSSIBLE PLAYERS FOR CARRYING OUT AN ACT OF AGROTERRORISM}

A probable list of motivated actors who could resort to Agroterrorism can be (i) States/Countries: but the probability of use is almost negligible. Covert use or support to terrorist or sub state actors cannot be ruled out in totality. (ii) Terrorist or non-state actors. (iii) Individuals/Organization: Disgruntled farmers, employees, environmental groups with specific goals may use biological agents for Agroterrorism. (iv) Organized crime: Organized white Collar criminals, speculators, stock markets dealers, private houses and corporations may all be potential candidates for use of Agroterrorism. For example, perpetrators may invest in stocks of one company and create agro terror in a rival company.

\section{GOALS FOR AGROTERRORISM}

(i) Political Goals :_The terrorists have been involved in violent crimes like bomb blasts and human killings. With the global coalition against terrorism, it would not be easier to have a safe haven. The use of raw violence also strengthens the resolve of the citizens to fight the terrorist. With pressure, difficulty arises in getting resources, recruitment and hideouts to conduct an act. Agroterrorism causes economic damage that could in addition help the political goals of the terrorist. The Rand Corporation observes that in addition to the traditional methods of terror, terrorists may change their strategy and "move towards the non-lethal end of the spectrum where command and control nodes and vulnerable infrastructure provide a rich set of targets". *32 (ii) Social Goals: The social costs of an agro terror incident also make it a potential candidate for terrorist use. The FMD and BSE (Bovine spongiform encephalopathy) disease in the United Kingdom is a pointer in this direction. Some of the possible social effects of Agroterrorism are: Tensions and conflict within communities, Loss of amenity and recreation, Communities experiencing permanent changes in land use, Loss of confidence in the systems' ability to control crises, Loss of trust in governance, Increased social isolation, Uncertainty, confusion and lack of continuity in public life. When the disease is zoonotic it increases the social costs which are associated with Agroterrorism.

Burial or burning of carcasses of dead animals also creates sociological and environmental problems. Existing food stocks not affected by the diseases could also be suspect and further cause economic harm above and beyond the diseased agro products. There are many other antecedent problems that could augment the original problem. There could be widespread unemployment, economic losses to the individual farmers in addition to the national loss. If the impact is 
high, it may also lead to huge financial compensation issues as well as social unrest. (iii) Economic Goals: The terrorist use of agro terror to create economic hardship in the target populace is an effective form of asymmetric warfare.

\section{AGROTERRORISM AND ORGANIZED CRIME}

Agroterrorism may also be used as a tool of organized crime by organized cartels to further their aims. It has been postulated by Dr. Floyd Horn administrator of the Agricultural Research Service in the US Senate that anti-agricultural biological agents could be used by the vested interest to manipulate the future trading or commodity markets* 33 . Similarly, it is postulated that rivals in agricultural products trading can use agricultural terrorism to gain an upper hand $* 34$.

\section{AGROTERRORISM AND SURROGATE WARFARE}

When the UK was struggling with the natural BSE outbreak the European Union banned beef import from the United Kingdom with effect from March 1996; the ban lasted for 10 years *35. The act was done to prevent the disease from entering the European Union, but the British saw it as a discriminatory economic measure. Similar was the case was when Belgian pork was banned following the outbreak of African Swine Fever (ASF) affecting the EU-Brussels relations. It is possible that any terrorist group/organized group of criminals could conduct such deliberate attack of Agroterrorism so as to create a rift between two allies or friends.

\section{AGROTERRORISM AND GENERATION OF FINANCE}

Organized criminal gangs might use terrorist acts to affect future trading and commodity market* 36 . It is also postulated that the terrorist might use the same method for finance generation. Terrorist or organized crime perpetrators might invest in the stock in one country/production base of a company and plan and execute an attack on a rival country/production base. This leads to a paradoxical situation where it could be possible for terrorist organizations to generate income from their own acts of devastation * 37

\section{AGROTERRORISM: ENVIRONMENTALLY MOTIVATED}

Certain environmental activists could use Agroterrorism in reaction to various scientific developments in the field of agriculture if they believe it to be against the order of nature. It is documented that various such eco-terrorist groups have claimed responsibility for sabotaging university and biotechnology laboratories, attempted sabotage of nuclear power plants, slaughter of cattle and destruction of genetically engineered crops. *38

\section{DEALING WITH AGROTERRORISM: CASE STUDIES}

\section{A. The foot and mouth disease in the United Kingdom.}

One of the most dangerous and frightful epidemic was the Foot and Mouth Disease in the United Kingdom. It would be pertinent to draw points from the lessons learnt from the UK experience. It was observed that this form of terrorism if it occurs would differ from the normal terrorist activities in the sense that it would predominantly affect the rural community as compared to the urban communities seen in other forms of conventional and non-conventional terrorist activities. In general, there is a lack of animal and plant disease specialists especially in the rural sector i.e. the ratio of health care providers to the average population is less as compared to humans. The specific shortcomings of the UK system would help us to deal with the agro terror incident more efficiently as and when they occur. A UK Govt. Report*39 observed. (i) The first response was, slow sluggish and was not effectively coordinated. (ii) A gap in between the last epidemic and the 
present was of 32 years. So the knowledge of the government in responding to a crisis was limited, as farming practices had changed and this could be a major problem worldwide as the epidemics and large-scale diseases seem to have been overcome. (iii)The response of the Govt. was to see the event as an agricultural crisis, and not that of any economic or socio-political nature and this was a misjudgement. As and when the terrorist use agro terror it would precisely be for the latter reason. (iv)The veterinary resources apart, the logistic and managerial problems were also paramount, as the large scale nature of the event could not have been predicted. (v)People in the government sector worked overtime but the result could not be seen overnight. In other forms of terror, response can be quick and easily visible. This has a twin effect of not only causing demoralization in the response workers but also leads to a restless citizenry, unsure of the government's ability to respond to a crisis. (vi) Communication by the government in a rural community setup was poor. The differential reach of the media in the rural and urban areas can send a contradictory message and cause mistrust among the citizens

The lessons learnt are equally valuable and relevant for preparing for any deliberate attack on the farm sector or in dealing with Agroterrorism. (1) Maintain vigilance through international, national and local surveillance and reconnaissance. (2) Be prepared with comprehensive contingency plans, building mutual trust and confidence through training and practice. (3) React with speed and certainty to an emergency or escalating crisis by applying well-rehearsed crisis management procedures. (4) Explain policies, plans and practices by communicating with all interested parties comprehensively, clearly and consistently in a transparent and open way. (5) Respect local knowledge and delegate decisions wherever possible, without losing sight of the national strategy. (6) Apply risk assessment and cost benefit analysis within an appropriate economic model. (7) Use data and information management system that conform to recognised good practice in support of intelligence gathering and decision-making. (8) Have a legislative framework that gives the Government the powers needed to respond effectively to the emerging needs of a crisis. (9) Base policy decisions on the best available science and ensure that the processes for providing scientific advice are widely understood and trusted

Appendix 3 of the same report has some finding which affects the law enforcement community at the cutting edge level and would be useful for the law enforcement to formulate plans to deal with Agroterrorism. (i)Law enforcement officers were needed to be deployed basically at three levels for (a)Community relations, (b)Law enforcement issues' (c) Health and safety issues, due to crisis handling which would include roadblocks, mapping of routes, safe animal disposal and haulage to a disposal site. (ii) The job was overwhelming and stress full from the beginning "phone never stopped" was the response. (iii) Although the liaison desk was established co-ordination with other agencies was Ad hoc until the army took over. (iv) Most of the queries and job requirement tasks (like safe routes etc.) were not at hand and it was purely "learning on the job."(v)They were confused about the disease control plans. (vi)There was a lack of communication, which leads to long delays with undue distress and even duplication of efforts sometimes. (vii)There were a number of mental distress calls. (viii) The Ad hoc recruitment of slaughter agents was undertaken to deal with affected cattle and to slaughter and deal with post slaughter clean up. They were accused of incompetence in slaughtering, cleaning up and had poor communication skills. All these increased the distresses call to the law enforcement officials. (ix)There was an increase in stress among the police officers.

All these are reflective of the fact that any failure on the part of other responding agencies ultimately falls on the police. The police, being the visible arm of the government, may be expected to perform roles beyond its sphere and competency. 


\section{B. Avian Influenza or the Bird Flu of Asia}

The occurrence of bird flu, since 2003 and measures to combat it has many implications for preparations of Agroterrorism. The pandemic was caused by the H5NI strain of influenza. The lessons learnt were (i) Multi-sectoral planning especially between the various components of the farm sector in planning and implementation of response plans is essential. (ii) Early detection is key to reduce morbidity and mortality (iii) The most important lesson learnt was that containment and its planning would need commitment at the highest level from the police which may be required to assist the health sector for rapid containment. (iv)Indian, Indonesian and Myanmar experience showed that specialized teams assisting the local teams were an effective response system. (v) In Thailand the greatest success was the system of village Health volunteer system that created skilled volunteers in the public health sector especially in areas of surveillance. (vi)The role of law enforcement is paramount in preventing the possibility of rioting and social disturbances which should be an integral part of any response plan. (vii) The need for Personal Protective Equipment (PPE) stockpile which could be used in case of emergency. (viii)Good laboratory diagnostic capacities with standard operating procedures especially for transport are pivotal for any response. (ix)International travel, increase animal exports and migratory birds have the capacity to spread any biological event from region to region(x)The most important measures were practicing farm bio-security, culling and destruction of poultry (or any other agro product) combined with compensation to farmers and emergency vaccination. (xi) Avian influenza highlights the cultural and economic effects of any biological event if it involves a way of life especially in traditional societies like India and Asia. (xii)The events highlight the political commitment into multi agencies collaborations especially between the health, agricultural and law enforcement agencies to successfully contain any biological outbreak.

\section{AGRO-TERRORISM AND INDIA:}

Globally, India ranks first in terms of the highest net cropped area. Agriculture is the most important sector, contributing $23 \%$ of GDP and provided employment to $59 \%$ workforce as in $2016.70 \%$ of the population is predominantly dependent on agriculture for livelihood, of which $82 \%$ are small and marginal farmers $* 40$. India is today the top producer of milk, jute and pulses, second in wheat, rice, potato, cotton, sugarcane, groundnut, fruits and vegetables $* 41$. India is also the seventh largest agricultural exporter $* 42$.

Like in case of the developing world with reference to India the Capacity to monitor the agricultural pests and disease are limited, Farm security measures are minimal, Fragile farm economy could make an agro terror event worse and also there is a lack of awareness and expertise in risk assessment of the threat.

The following features of Indian and other Low - Middle income countries context make the farm sector vulnerable. (i)India is a predominantly agricultural economy with the green and white revolution increasing the value of agriculture as a share in the Indian economy. (ii)The breading of cattle sheep/goats and the poultry is in the hands of traditional small farmers. (iii)The poultry industry although slightly better organized is also mostly in the small scale sector. (iv) The breeding and draft animals are predominately in the unorganized sector. (v) Cattle fairs like Pushkar in Rajasthan and Sonepur in Bihar attract lakhs of farmers who are cramped in a small area for days and then the animals disperse to all parts of the country, an ideal situation for the intentional introduction and spread of disease. (vi)There has been extensive breading of exotic (Jersey, Holsteins) and Indian cows, exotic (Scottish, Australian) and Indian sheep. These crossbreeds are more susceptible to diseases. (vii)The country ranks first with respect to cattle and buffalos, second in goats, third in sheep and seventh in poultry production in the world. This huge susceptible population of animals with 
the unrestricted movement of animals in the country with little or no systematic vaccination makes it highly vulnerable.

\section{The 2015 cotton Leaf Curl Disease of Punjab}

The cotton leaf curl disease (CLCuD) is a virus transmitted by whiteflies that cause extensive damage to the most important nonfood crop of India. The disease caused by whiteflies is common in north-western India and adjoining areas of Pakistan. The disease usually breaks out in Pakistan and then spreads to the contagious areas of India mostly Punjab. There are many viral strains the important of which are Multan virus (CLCuMuV), Cotton leaf curl Kokhran virus-Burewala (CLCuKoV-Bu) and their interspecies recombinants. The 2015 outbreak was different. It caused the destruction of around two-third of the crop causing huge losses in crores and around 15 farmers committed suicide leading to protests and sociopolitical chaos. It was curiously caused by a clade of the Multan Virus CLCuMuV which was seen to be recombinant of strains and was not preceded and followed by a similar outbreak in the Pakistan fields. They were surprisingly detected only in experimental cotton plants in two cotton research institutes of Pakistan in Vehari and Multan. Both of these institutes maintain infective viral complexes from all previous epidemics. The trans-border disease with no involvement in Pakistan's fields except in the research institute fields was highly suspicious. *43

\section{RECOMMENDATIONS: STRATEGIC PLANS FOR AGROTERRORISM.}

Strategic plans should be in place to address the critical issues. This should include national and state level plans and include inter and intra-governmental cooperation, with defined roles and responsibilities, involvement of the private sector, and public awareness through education. Critical gaps could be the role of the intelligence agencies in getting relevant triggers, the law enforcement's ability in dealing with a new problem and soliciting private partnership and funding. International cooperation would be needed in research; detection, identification, and monitoring of biological agents and in epidemiology; disease containment, including development and application of vaccines, therapeutics, and newer forms of treatments. Consequence management, financial relief, and restoration of affected areas should also receive priority.

The WHO recommended strategies for Pandemic Preparedness are: Reduce exposure to the strain (biological agent), strengthen early warning system, device rapid containment operations, capacity building to cope with epidemics, co-ordination of global scientific research and development. The key issues are Multi-sectoral planning and implementation, Early detection via training in surveillance at the grass root level and each country voluntarily complying with the International Health Regulations (IHR)

\section{Strategies}

Strategies to deal with Agroterrorism need to have a holistic approach as the threat is extremely wide and amorphous. It would be prudent to focus on certain selected high consequences plausible threats rather than focusing on the entire gamut of agents. The strategies could be divided into the following categories.

(i) Strategies at the International level. (ii) Strategies at the national level. (iii) Strategies at the level of the farm. (iv) Strategies at the level of the biological agent. (v)Strategies for response to an event or deployment

The strategies would be aimed at the objectives of preventing the terrorist use of biological weapon agents and alleviate the effects of the use of a biological agent on Agriculture. 


\section{Strategies at the International Level}

(i)There should be renewed efforts to foster international co-operation in the field of research, surveillance, preparation of response plans with sharing of best practices. (ii) The Office of International Epizootics (OIE) can be a model agency for co-ordination of response against Agroterrorism and as a resource centre for help. (iii) There is a possibility that terrorists could use any conventional outbreak of disease to obtain a pathogen. The Aum Shinrikyo sect had used the Ebola outbreak in Africa to obtain the viruses purported to be used in Japan *44. There should be a global coalition for the collection and dissemination of information that could be integrated with intelligence inputs. (iv)There should be a central repository for the vaccines pool, with contributions from various nations be distributed in need of the hour.

\section{Strategies at the National Level.}

(i)All concerned national agencies should be identified as a partner in response with a well-defined role. (ii)A list of biological agents which are of importance that could be acquired and used should be prepared. (iii)Create a genomic database of potential agricultural pathogens of concern for commercial crops. It should be matched with the same for adversarial countries especially if they share a common border. These pathogens can be monitored for any new strains or clades of viruses. (iv)Develop and conceptualize scenarios of attack, that are highly probable using modelling and develop collective response strategies for a group of related pathogens. (v)Develop and conduct tabletop exercises based on the above scenario with all partners and develop joint training exercises. Test, evaluate and improve the response plans. (vi)Identify the pathways through which biological agents (plant, animal pathogens and pests) enter or have the potential to enter the host country and develop intelligence inputs and strategies to deal with the same. (vii)On the line of the integrated disease surveillance projects for humans develop holistic surveillance projects for major and emerging threats of plants and animal's disease for timely detection of outbreaks. Have linkages with diagnostic laboratories for disease confirmation. Develop a tracking system to monitor the spread of an outbreak. (viii)Develop a research base within the country for preventive measures. (ix)Reorient the intelligence agencies to make them aware of the threat and reorient intelligence resources and strategies. (x)Develop an efficient network of animal and plant health laboratories with accurate diagnostic protocols and procedures with sufficient surge capacity to deal with any emergency. (xii)Training and education should be planned not only in the medical curriculum of veterinary colleges but also other first responders.

\section{Strategies at the Farm Levels}

(i)Strategies at the farm levels are the most important yet the weakest link in defence against Agroterrorism. How well educated and vigilant is the farmer would decide how quickly would an event be recognized and a response plan put in place. They should be familiar with clinical presentation of most important threat agents. (ii)Farmers and handlers should be vigilant and ward off suspicious queries and movements around the farms for both plants and animals. (iii)Crop rotation should be encouraged to prevent plant disease.

\section{Strategies at the Pathogen Level}

(i)The O.I.E. has prepared a list of plant and animal pathogen which are likely candidates for Agroterrorism. A close watch should be kept on them and an effective surveillance system be established. Farm hygiene practices should be developed; vectors should be controlled for diseases like Rift-Valley fevers. (ii) Industry and Academic institutions should be encouraged to forge, partnerships with the state to develop countermeasures like vaccines and anti-viral drugs 
which are broad spectrum and are effective against bio-agents so identified as possible candidates in Agroterrorism. (iii) The pathogenesis and epidemiology of common diseases of concern and their prophylaxis and control techniques should be known to all players. (iv) Field testing kits should be developed for common diseases and they should be standardized and be readily available in the field for quick detection. (v)Genomic characterization of important agents and a repository of isolates should be available for forensic purposes. This would also help in predicting its potential spread, virulence and aid in developing modelling programs for the agents.

\section{Strategies for Response to an Event}

(i) Separate response plans should be formulated for the local, regional and national level, with clearly defined roles and responsibilities for each agency. (ii) A Quick reaction team to reach the spot and regional and national teams could be established for specialist consultation and advisory roles. (iii) National agencies should train the state units and all plans at each level should be functionally integrated. (iv)Plans should cater to mass disposal of carcasses with special care for environmental pollution mitigation, the spread of disease with due consideration on the political and economic, social and psychological aspects of the problem. (v)Diagnostic and forensic capabilities should be identified and augmented with a surge capacity. Co-ordination should be ensured between Law Enforcement, animal and public health authorities. (vi)An organised public and media education plan and press releases should cater to heightened tension or a hoax to reduce fear and panic and to control rumours. (vii) An effective Communication policy should exist as shown by the UK experience in dealing with the FMD, as most affected people would be in the rural sector. (viii) Public should be well informed as the economic impact of agro terror would largely be influenced by consumer behaviour. (ix) A planned vaccine usage policy should be in place as vaccines in the animal sector are scarce resources.

\section{Bio-Security and Scientific Interventions}

Strict international and national biosecurity methods should be put up in place so that access to agricultural pathogens from certified laboratories is stringent and only genuine researchers have access to the biological agents. This is important in the case of agricultural pathogens because these agents do not need many manipulations for weaponization. Strict regime for Gain of Functions experiments and dual-use equipment and experiments should be in place.

\section{CONCLUSIONS}

COVID 19 could lead to a resurgence in interest among terrorists for using unconventional weapons as the pandemic has left government resources being ruthlessly stressed. The feasibility and practicality of Agroterrorism can be gauged from the various State Biological weapon programs in the past. The agents can be easily acquired and transported and are accessible across the globe. The impacts of Agroterrorism are beyond plant and animal destruction but predominately economic affect food security, social harmony, tourism and create political and social turmoil. It is difficult to predict the possibility and the scale of attack in agro terrorism, but the threat is real and the vulnerability of the sector especially in the developing world suggests that the risk is high coupled with a lower capacity to deal with the consequences in a continuously changing security environment

The terror effect of Agroterrorism is less than that of the agents used against humans but feasibility and practicality are higher. Preventing an act of Agroterrorism is as impractical as is the act of eliminating plant and animal diseases in their natural state. However, interdisciplinary effort, international cooperation and interagency co-ordination 
can help to mitigate the threat. A good communication strategy coupled with joint training and coordinated response plans are fundamental in dealing with the threat. The absolute expanse of agricultural landscape, combined with the ease of obtaining and using a biological agent in Agroterrorism, the wide array of players (terrorist, environmentalist, white collar criminals and individual) who could employ the biological agent makes the scenario unimaginable. The best solution would be to make optimum utilization of resources and formulate dual use plans offering solutions which would offer enhanced animal, plant and public health security even in the absence of Agroterrorism. Threat of Agroterrorism requires countries to work proactively and develop shared strategies to thwart the next deliberate outbreak. There is a need to continue to strengthen the operational and strategic collaboration between the health sector, the intelligence community and law enforcement. Although an act of agro terrorism may not be the typical big bang, yet the enormous economic damage with a favorable cost benefit ratio makes agro terrorism a plausible threat. These are reasons enough to invest in resources and activities that would be justified on the general grounds of promoting security, food safety, and the betterment of the rural masses.

\section{REFERENCES}

1. Robert Pear, "U.S. Health Chief, Stepping Down, Issues Warning," The New York Times, December 4, 2004.

2. Corrie Brown, "Agro-Terrorism: A Cause for Alarm," The Monitor: Nonproliferation, Demilitarization, and Arms Control, Winter-Spring 1999 p. 7.

3. Geissler, Erhard. "Biological Warfare Activities in Germany, 1923-45," Geissler, Erhard and Moon, John Ellis van Courtland, eds. Biological Warfare from the Middle Ages to 1945, (New York: Oxford University Press, 1999), pp. 120.

4. Ibid pp. 121

5. Ibid, pp. 111,117

6. Harris, Sheldon. "The Japanese Biological Warfare Program: An Overview," in Geissler and Moon, pp. 139.

7. Ibid, pp. 143,144

8. Lepick, Olivier. "French Activities Related to Biological Warfare, 1919-1945," in Geissler and Moon, pp. 83.

9. $\quad$ Ibid, pp. 86

10. Bernstein, B.J. "The Birth of the U.S. Biological Warfare Program," Scientific American, 1987, 256: pp. 116-121. (no 10)

11. Department of the Army, Textbook of Military Medicine, (Falls Church, VA: Office of the Surgeon General, 1997), p. 461

12. Ibid, p. 51

13. SIPRI, The Problem of Chemical and Biological Warfare, Volume II: CB Weapons Today (Stockholm: Almkvist and Wiksell, 1973), pp. 234.

14. Ibid

15. Livingston, NC and Douglass JD. "CBW: The Poor Man's Atomic Bomb," National Security Papers, Vol. 1, Cambridge, MA: Institute for Foreign Policy Analysis, Inc., 1984)

16. Defense Intelligence Agency, Chemical and Biological Warfare Capabilities -- USSR, March 1977, DST-1600S-034-76-SUP 1, Unclassified, pp. 245-7.

17. Defense Intelligence Agency, Chemical and Biological Warfare Capabilities -- USSR, March 1977, DST-1600S-034-76-SUP 
1, Unclassified, pp. 236

18. Defense Intelligence Agency, Chemical and Biological Warfare Capabilities -- USSR, March 1977, DST-1600S-034-76-SUP 1, Unclassified, pp. 240-245

19. Defense Intelligence Agency, March 1977, pp. 238.

20. Defense Intelligence Agency, March 1977, pp. 240.

21. Defense Intelligence Agency, March 1977, pp. 241.

22. COVID 1919 or Opportunistic Bioterrorism? Sharad S.Chauhan Unistar books (1 January 2020)

23. Dill, V., \& Eschbaumer, M. (2020). Cell culture propagation of foot-and-mouth disease virus: Adaptive amino acid substitutions in structural proteins and their functional implications. Virus genes, 56(1), 1-15.

24. Sharad S Chauhan, Biological Weapons, APH Publication Corporation, 2004

25. Thompson, D., P. Muriel, D. Russell, P. Osborne, A. Bromley, M. Rowland, S. Creigh-Tyte, and C. Brown. 2002. Economic costs of the foot and mouth disease outbreak in the United Kingdom, Rev Sci Tech Off Int Epiz 21(3):675-687, <http:// www.defra.gov.uk/corporate/inquiries/index.asp>

26. $R$ McMahon, J. Review of the Legislative Aspects of the 2001 Foot and Mouth Disease Outbreak in Northern Ireland. Pricewaterhouse Coopers Independent Review of Foot and Mouth Disease in Northern Ireland. Working Paper 1.( June 2002).

27. Corrie Brown, "Agro-Terrorism: A Cause for Alarm," The Monitor: Nonproliferation, Demilitarization, and Arms Control, Winter-Spring 1999 p. 7.

28. Veterinary Services, "Foot-and-Mouth Disease," United States Department of Agriculture Animal and Plant Health Inspection Service Fact-sheet (July 1998), http://www.aphis/usda/gov/oa/pups/fsfmd.html

29. Michael V. Dunn, "The Threat of Bioterrorism to US Agriculture” Annals of the New York Academy of Sciences 894 (1999), pp. 184-188.

30. Debora MacKenzie, “Run, Radish, Run,” New Scientist, December 18, 1999, p. 38.

31. Delgado, C., M. Rosegrant, H. Steinfeld, S. Ehui, and C. Courbois. 1999. Livestock to 2020: The next food revolution. Food, Agriculture, and the Environment Discussion Paper 28. International Food Policy Research Institute, Food and Agriculture Organization of the United Nations, International Livestock Research Institute, May 1999, <http://www.fao.org/ag/aga/agal/ lvst2020/20201/pdf>

32. Ian O. Lesser, Bruce Hoffman, John Arquilla, David Ronfeldt, and Michele Zanini, Countering the New Terrorism (Santa Monica, CA: RAND, 1999) pp. 71-72.

33. US Senate, Armed Services Committee, Emerging Threats and Capabilities Subcommittee, October 27, 1999.

34. Robert P. Kadlec, "Biological Weapons for Waging Economic Warfare," Airpower, http://www.airpower.maxwell.af.mil/airchronicles/battle/chp10.html

35. End to 10-year British beef ban". BBC News. 3 May 2006.

36. US Senate, Armed Services Committee, Emerging Threats and Capabilities Subcommittee, October 27, 1999.

37. Sharad S Chauhan, Biological Weapons, APH Publication Corporation, 2004 pp268-273

38. Bard Knickerbocker, "Concerns Rise as Ecoterrorists Expand Aim: Biotech Research and Fur Farms are the Latest Targets of 
Fringe Groups on the Far Left," Christian Science Monitor, April 3, 2000, p.3; Laqueur, The New Terrorism, pp. 199-204.

39. UK the homepage for the lessons learnt from the 2001 outbreak of foot and mouth disease of the UK can be found at http://www.cabinet-office.gov.uk/fmd/index.htm

40. Sharma, V. P. (2007). India's agrarian crisis and smallholder producers' participation in new farm supply chain initiatives: a case study of contract farming.

41. India at a glance. http://www.fao.org/india/fao-in-india/india-at-a-glance/en/

42. India's agricultural exports climb to record high. USDAFAS, 2014.https://www.fas.usda.gov/data/india-sagricultural-exportsclimb-record-high

43. Datta, Vanlalhmuaka, and S. K. Dwivedi, Agroterrorism in Indian Context, Defence Life Science Journal, 5, 2, $125-132$ (2020), DOI: 10.14429/dlsj.5.15568

44. Cole LA.The spectre of biological weapons. Sci Am 1996; 275: 60-65. 